\title{
How Literature Informs Notions of Leadership
}

\author{
Gregory L. Eastwood \\ University Professor, State University of New York \\ Center for Bioethics and Humanities \\ 618 Irving Avenue \\ SUNY Upstate Medical University \\ Syracuse, NY 13210 \\ eastwood@upstate.edu
}

\begin{abstract}
Novels, short stories, plays, and poetry can help us understand the character traits, abilities, and contexts of leadership in ways that didactic methods cannot. I present examples of the use of literature in its several forms to stimulate thought and discussion and to enrich the understanding of the characteristics and dynamics of leadership. I consider the character traits of honesty, courage, adherence to principles, respect, ego, humility, calmness, and perseverance, and the abilities to listen, to select good people, and to know oneself. I also identify some of the conditions and contexts of leadership, such as chance, environment, interdependence, and the roles of heroes, mentors, and peers. These examples from literature are not intended to be authoritative but rather illustrative, with the intent that they will encourage others to seek and use their own examples in the process of understanding leadership and becoming good leaders.
\end{abstract}

\section{Introduction}

I teach a seminar course titled Let's Talk About Ethical Leadership to a diverse group including undergraduate, graduate, and professional students as well as mid-career professionals and executives. During this course we meet some admired leaders, engage in several exercises that further our understanding of ethical leadership, and discuss in depth the character traits, abilities, and contexts of good leadership.

Some of the character traits we consider are honesty, courage, adherence to principles, respect, ego, humility, calmness, and perseverance. The leadership abilities we examine include the abilities to listen, to select good people, and to know one's self. The distinction between character traits and abilities is not discrete. In general, I regard character traits as qualities that are innate to the 
person, although they can be developed. I see leadership abilities as skills that can be developed with practice, although here, too, some individuals begin with better equipment than others. During the seminar, we also identify some of the conditions and contexts of leadership, such as chance, environment, peers, mentors, interdependence, and the roles of heroes.

Leadership is difficult to define and a difficult subject to teach. I have said elsewhere that precise definition of leadership is difficult although we think we know it when we see it (Eastwood, 1998). Sample (2002) observes the concept of leadership is elusive and tricky... hard to define in a way satisfactory to everyone. Shaw (2005) believes leadership is a process using persuasion and set by example thereby others are motivated to act, which describes what leadership does but not what it is. Regardless of the difficulties we have in defining leadership, there seems to be a general acceptance of the need for good leadership and the need to teach it. Courses abound in academia, industry, the military, on-line, and elsewhere. Many methods are used to teach leadership, including analysis of leadership characteristics and styles, case studies, biographical studies, autobiographical writing, and storytelling (Albert \& Vadla, 2009; Doo, 2005; Pillai \& Stites-Doe, 2003; Sample, 2002; Shaw, K. A., 2005).

Sample (2002) emphasizes the importance of reading in his chapter "You Are What You Read," arguing that leaders are heavily influenced by what they read and they would be better served to spend their time reading the masterpieces of literature than the contemporary news. Fiction has had limited application in the teaching of leadership in the classroom (Pillai \& Stites-Doe, 2003), particularly in business schools (Aisner, 2008; Shaw, M. E., 2006) to study decision-making and other aspects of leadership.

In the course I teach, excerpts from literature, including fiction but also plays, poetry and other writings, are integrated with other methods of instruction, such as readings from standard texts and essays prepared especially for the course and review of information in the print and electronic media. Participants in the course also report on interviews with leaders in the community, engage in interactive discussion with acknowledged leaders, and create their own essays on aspects of leadership.

I have found that novels, short stories, plays, and poetry - the individuals depicted in them and the situations developed - help the students understand the character traits, skills, and context of leadership in ways that didactic methods cannot. For example, we see honesty or courage in action and there is a richness which one cannot experience simply by discussing honesty or courage as an academic exercise. The examples from literature stimulate conversations that students relate 
to their own experience and development and the students indicate that they have been able to perceive concepts and understand their own capabilities better.

I will present examples of the use of literature in its several forms to enrich the understanding of the characteristics and dynamics of leadership and thereby recommend this method for use in the process of learning about leadership. In all instances, except one where it is unnecessary, I provide a context and commentary. I expect that readers likely will think of many other examples from their own literary experiences. But first, let us consider John Steinbeck's view of the role of literature, which I believe sets an expectation for the uses of literature in all applications.

\section{John Steinbeck's View of the Role of Literature}

John Steinbeck was awarded the 1962 Nobel Prize in Literature for his realistic, imaginative writings that combined sympathetic humor and a keen social perception. His uncompromising views about the purpose and use of literature are relevant to the development of leaders. In Steinbeck's Nobel Prize Banquet Speech, December 10, 1962 he said:

Literature was not promulgated by a pale and emasculated critical priesthood singing their litanies in empty churches - nor is it a game for the cloistered elect, the tinhorn mendicants of low calorie despair.

Literature is as old as speech. It grew out of human need for it, and it has not changed except to become more needed...

The ancient commission of the writer has not changed. He is charged with exposing our many grievous faults and failures, with dredging up to the light our dark and dangerous dreams for the purpose of improvement.

Furthermore, the writer is delegated to declare and to celebrate man's proven capacity for greatness of heart and spirit... for courage, compassion and love. In the endless war against weakness and despair, these are the bright rally-flags of hope and of emulation. 
I hold that a writer who does not passionately believe in the perfectibility of man has no dedication nor any membership in literature.

\section{Character Traits}

\section{Integrity, Honesty, Higher Principles, Courage, Leading by Example, Respect, Tolerance, Humility}

Harper Lee's only novel, To Kill a Mockingbird (1960), tells the story of Atticus Finch, a lawyer in a small southern town in the 1930s, who accepts the responsibility of defending Tom Robinson, a black man accused of rape. The book's narrator is Atticus's eight-year old daughter, Jean Louise, who generally goes by Scout. Her brother, Jem, is 12. Their mother had died several years before. The novel's main plot is augmented by several subplots and stories, many of which provide examples of the characteristics indicated.

Scout and Jem receive harsh criticism at school for their father's decision to defend Tom Robinson. Scout discusses this with Atticus.

Scout: Then why did Cecil say you defended niggers? ...

Atticus: I'm simply defending a Negro - his name's Tom

Robinson. ...there's some high talk around town to the effect that I shouldn't do much about defending this man. ...

Scout: If you shouldn't be defendin' him, then why are you doin' it?

Atticus: For a number of reasons. ... if I didn't I couldn't hold up my head in town, I couldn't represent this county in the legislature, I couldn't even tell you or Jem not to do something again...

Atticus: Simply because we were licked a hundred years before we started is no reason for us not to try to win.

This last comment by Atticus reveals one of his fundamental beliefs and something that should guide good leaders, namely, there are reasons of principle that determine whether to engage in something, and they transcend winning. We revisit this below when we consider Higher Principles. 
An independent story, which can be appreciated without much knowledge of the rest of the book, appears in Chapter 10. In it, Atticus exemplifies a combination of courage, humility, and accurate self-awareness. It begins,

Atticus was feeble: he was nearly fifty. When Jem and I asked him why he was so old, he said he got started late, which we felt reflected upon his abilities and manliness. He was much older than the parents of our school contemporaries, and there was nothing Jem or I could say about him when our classmates said, " $M y$ father - "

Later in the chapter, a rapid dog appears down the street from the Finch home and the housekeeper calls Atticus in his law office. He arrives home with Sheriff Tate, who has a rifle with which to shoot the dog. They get out of the car at a respectful distance from the dog and Tate gives the rifle to Atticus. This astounds Scout and Jem, who think their father has no abilities. Atticus says that he has not shot a gun in thirty years and Tate should shoot the dog. Tate persists, insisting that Atticus is the best shot in the county. Atticus takes the gun, lifts it, pushes his glasses to his forehead, they slip, he drops them to the street and they break, he rubs his eyes, blinks, and "With movements so swift they seemed simultaneous, Atticus's hand yanked a ball-tipped lever as he brought the gun to his shoulder. The rifle cracked. [The dog] leaped, flopped over and crumpled on the sidewalk..." - a dead shot. After, Jem and Scout discuss this with a neighbor, Miss Maudie, having developed a new admiration and respect for their father, and ask her why Atticus never said anything about his shooting abilities and why he never hunts.

Miss Maudie: If your father's anything, he's civilized in his heart. Marksmanship's a gift of God, a talent- oh, you have to practice to make it perfect... I think maybe he put his gun down when he realized that God had given him an unfair advantage over most living things. I guess he decided he wouldn't shoot til he had to, and he had to today.

Scout: Looks like he'd be proud of it.

Miss Maudie: People in their right minds never take pride in their talents.

\section{Higher Principles}

A [person] does not fight merely to win. (Cyrano de Bergerac, Edmond Rostand) 
Rostand's Cyrano de Bergerac, a play about an incurable romantic and idealist with a big nose, resonates with me. Maybe it is because I have a big nose, too. After all, Cyrano says, "A great nose indicates a great man."

Cyrano always seemed to be spoiling for a fight, defending some principle. Cyrano was driven to win, certainly with his sword, but even more with his wits. So when he says, at the end of the play, "A man does not fight merely to win," initially I was surprised. Merely winning suggests that there is a greater purpose than winning. But I understand Cyrano when I recall John F. Kennedy's contention that "In the age-old contest between popularity and principle, only those willing to lose for their convictions are deserving of posterity's approval" (Profiles in Courage, 1955).

What Cyrano and Kennedy are saying is that some principles are more important than winning, so important that we are willing to risk losing for them. This is what Atticus Finch in the section above means when he says, "Simply because we were licked a hundred years before we started is no reason for us not to try to win." A person may fight for certain things even if winning is unlikely. For most of us this translates practically to picking our battles and not engaging in others.

I believe that most effective leaders are driven by principles. And most effective leaders want to win or accomplish something important to them. But what happens when winning becomes more important than the principle? The world is full of examples of that, in which hubris dictates action, and this has been around since the early Greeks who wrote plays about it. But Cyrano and JFK caution us that winning is not our highest calling and that fighting for what we believe in is.

\section{Courage}

Gilead, by Marilynne Robinson (2004), an extended letter by John Ames, a 76year old minister, to his seven-year old son, Robby. Ames lost his first wife and child and after a long hiatus, married his current wife, much his junior. He anticipates that he will die soon and the letter is a substitute for his anticipated absence during the boy's developing years. In it, Robinson explores values, relationships (the friendship of Ames and another minister in town, Robert Boughton, is especially rich), religious faith, and other aspects of life that Ames values. Ames considers courage and relates it to a reason to live:

Theologians talk about a prevenient grace that precedes grace itself and allows us to accept it. I think there must also be a prevenient courage that allows us to be brave - that is, to acknowledge that 
there is more beauty than our eyes can bear, that precious things have been put into our hands and to do nothing to honor them is to do great harm. And therefore, this courage allows us... to make ourselves useful.

Ralph Waldo Emerson also wrote of courage in his The Concord Hymn (1836), sung July 4, 1837 during Concord's Independence Day celebration to commemorate the courage and actions of a small number of Massachusetts militia against British regulars at Concord Bridge April 17, 1775. It begins and ends thus:

By the rude bridge that arched the flood, Their flag to April's breeze unfurled, Here once the embattled farmers stood, And fired the shot heard round the world.

Spirit, that made those heroes dare, To die, and leave their children free, Bid Time and Nature gently spare

The shaft we raise to them and thee.

\section{Ego}

Leaders in the corporate world, academia, government, and almost everywhere intentionally attract bright, accomplished individuals who have a great interest in their own success, some of whom are perceived as having "big egos." Leaders have every reason to respect all such individuals and try to support them. However, a perceived "big ego" sometimes raises the suspicion that actually it is a fragile ego that is protected by whatever mechanisms its owner has found useful to be successful - aggressiveness, dominance, establishment of "turf," need for reassurance, and so forth - and such individuals may in fact be somewhat insecure. What one might expect from a big ego in the literal psychological sense - humility, magnanimity, tolerance, self confidence, constructive use of power may not be evident or disappears once the walls of the fortress are threatened. The "big egos" of an organization provide some of the greatest challenges to leaders, largely because the "big egos" often contribute in great measure to the success of the organization and, in fact, are prevalent among our own leaders.

I have used two short stories by Nathaniel Hawthorne to illustrate the opposing character traits of ego, as it is used to describe a person's exaggerated sense of importance, and humility. 
In Egotism; or, the Bosom Serpent, Hawthorne tells the story of a man who is tormented by what he believes to be a serpent in his chest. At one point he says,

Could I for one instant forget myself, the serpent might not abide within me. It is my diseased self-contemplation that has engendered and nourished him.

“...my diseased self-contemplation..." among other aspects of the story are grist for discussion about leadership.

\section{Humility}

The second story is one of my favorites. The Great Stone Face, relates the life of Ernest, who lives his entire life in a valley in New Hampshire under the benign influence of a natural rock formation that had the appearance of a man's facial profile. Anyone familiar with New Hampshire knows that this is Franconia Notch and the Great Stone Face, a rock formation that had endured for geologic ages, that unfortunately collapsed in 2003.

A prophecy in the valley, since it was inhabited by Native-Americans, anticipates that a child shall be born there and grow to be a great and noble man. Ernest, when he hears this from his mother as a small boy, begins his lifelong hope that he will live to see this person. Several times as Ernest grows and ages, one or another renown native son returns to be acclaimed as the incarnation of the Great Stone Face - Mr. Gathergold, a wealthy merchant; Blood and Thunder, a retired general; Old Stony Phiz, a former politician - but each in time is found to fall short of the expectation and is forgotten. Yet Ernest continues to hope. As Ernest matures, he discourses with his fellows about life and gradually becomes known widely for his wisdom, receiving visitors from afar.

And Ernest had ceased to be obscure. Unsought for, undesired, had come the fame which so many seek, and made him known in the great world, beyond the limits of the valley in which he had dwelt so quietly... for the report had gone abroad that this simple husbandman had ideas unlike those of other men, not gained from books, but of a higher tone - a tranquil and familiar majesty, as if he had been talking with the angels as his daily friends. Whether it were sage, statesman, or philanthropist, Ernest received these visitors with the gentle sincerity that had characterized him from boyhood, and spoke freely with them of whatever came uppermost, or lay deepest in his heart or their own... Pensive with the fullness of such discourse, his guests took leave and went their way; and 
passing up the valley, paused to look at the Great Stone Face, imagining that they had seen its likeness in a human countenance, but could not remember where.

A poet of "wonderful endowments," also a native of the valley, who "had spent the greater part of his life at a distance from that romantic region, pouring out his sweet music amid the bustle and din of cities," chose to return and visit Ernest. At first, Ernest hoped that the prophecy might be fulfilled in the poet but soon both men realized that the poet was not the incarnation of the Great Stone Face. Then,

At the hour of sunset, as had long been his frequent custom, Ernest was to discourse to an assemblage of the neighboring inhabitants in the open air. He and the poet, arm in arm... proceeded to the spot.

Ernest, standing on a slight elevation, addressed the people.

His words had power... At a distance... high up in the golden light of the setting sun, appeared the Great Stone Face, with hoary mists around it, like the white hairs around the brow of Ernest...

At that moment... the face of Ernest assumed a grandeur of expression, so imbued with benevolence, that the poet, by an irresistible impulse, threw his arms aloft and shouted - 'Behold! Behold!! Ernest is himself the likeness of the Great Stone Face!'

Then all the people looked and saw that what the deep-sighted poet said was true. The prophecy was fulfilled. But Ernest, having finished what he had to say, took the poet's arm, and walked slowly homeward, still hoping that some wiser and better man than himself would by and by appear, bearing a resemblance to the Great Stone Face.

A humble leader knows his/her own abilities, unexaggerated and realistic, and may even be proud of some of them, but does not flaunt them and knows that others also have abilities, some of which may augment or exceed their own.

\section{Calmness and Imperturbability}

...no quality takes rank with imperturbability... Imperturbability means coolness and presence of mind under all circumstances, calmness amid storm, clearness of judgment in moments of grave peril... It is the quality which is most appreciated by the laity 
though often misunderstood by them... (William Osler, Valedictory Address, University of Pennsylvania, 1889)

William Osler, a respected physician of the late 1800s - early 1900s, who held prestigious positions at McGill University, the University of Pennsylvania, Johns Hopkins University, and Oxford University, profoundly influenced the practice of medicine and the behavior of physicians that still persists. Although he lived in an era in which physicians were somewhat paternalistic and aloof (we hope that is fading), what he says about calmness and imperturbability I believe is relevant to leadership. People want their leaders to appear unflustered and in control. This is a big order because all leaders sometimes get angry, feel control slipping away, and become nervous. Some of us innately are calmer than others, but all of us can work on this. Aristotle says that we become what we do repeatedly (e.g., "It is by doing just acts that the just man is produced." - The Nicomachean Ethics). I believe that if we practice calmness, we can become calmer.

\section{Perseverance}

David Wagoner's The Cherry Tree (2008) speaks for itself about perseverance. For a cherry tree, this type of perseverance is innate and thus I would define as a character trait of the tree, to the extent that a tree can have character. I believe perseverance is a character trait of leaders, and whether it is innate or developed is an argument that probably applies in some degree to all character traits.

Out of the nursery and into the garden where it rooted and survived its first hard winter, then a few years of freedom while it blossomed, put out its first tentative branches, withstood

the insects and the poisons for insects, developed strange ideas about its height

and suffered the pruning of its quirks and clutters, its self-indulgent thrusts

and the infighting of stems at cross purposes year after year. Each April it forgot

why it couldn't do what it had to do, and always after blossoms, fruit, and leaf-fall, was shown once more what simply couldn't happen. Its oldest branches now, the survivors carved by knife blades, rain, and wind, are sending shoots straight up, blood red, into the light again. 


\begin{abstract}
Abilities

\section{Ability to Listen}

The narrator of Primary Colors is a young political aide who describes what it is like to talk with someone who really listens. At the book's beginning, he is walking with the main character, who is modeled after former President Bill Clinton. This description is characteristic of how others have described Bill Clinton.
\end{abstract}

He was in heavy listening mode, the most aggressive listening the world has ever known: aerobic listening. It is an intense, disconcerting phenomenon - as if he were hearing quicker than you can get the words out, as if he were sucking the information out of you. (Anonymous. Primary Colors. A Novel of Politics, 1996)

We usually think of listening as something we do (or not do) when someone else is talking. That is the commonly understood form of listening and one in which good leaders become adept. Although this form of listening may seem, at first, to be a passive experience, listening as described in Primary Colors can be an active, energy requiring process, sometimes even an intense one. A listener like this commands our attention, makes us appreciative of the listener, and may even encourage us to communicate better.

Clearly, the roles of listener and speaker change in any conversation, but leaders often find themselves in situations in which they are expected mostly to listen. Good listening requires the ability to focus and pay attention. Some leaders naturally are interested in what other people have to say; others need to work on that skill. Listening is of value to both the sender and the receiver. People want to know that their point of view is heard by someone who is in authority and who cares. They may want something to be done or to be able to contribute to the decision-making process. The listener also benefits. This is how one learns a great deal of information.

As I have studied listening, I have discovered other dimensions of listening that reinforce the mode of listening described above. One is to listen to my own reactions. Why am I pleased, grateful, frustrated, or angry? Also, what do I have stored in my brain from experience or knowledge that I can listen to and is relevant to this conversation? 
Listening in its broad meaning also includes paying attention to nonverbal cues, such as body language, style of interaction, habits, punctuality, demeanor, mood, dress, and the like, all of which may be helpful in understanding and working with another person and in learning useful information.

Finally, the broadest form of listening is to be attentive to all inputs of information as much of the time as you can. This is related to the observation of Louis Pasteur, the French microbiologist (1822-1895), who said, "Chance favors the prepared mind." Many important discoveries have been made because someone has been "listening" with a prepared mind (e.g., the discoveries of penicillin and radiation) and countless "ah-ha's" have been uttered by leaders whose receptors for new information were ready for it.

\section{Ability to Select Good People}

That Lincoln... made the unprecedented decision to incorporate his eminent rivals into his political family, the cabinet, was evidence of a profound self-confidence...

...Lincoln's political genius... enabled him to form friendships with men who had previously opposed him; to repair injured feelings...; to assume responsibility for the failures of subordinates; to share credit with ease; and to learn from mistakes...

...in the hands of a truly great politician the qualities we generally associate with decency and morality - kindness, sensitivity, compassion, honesty, and empathy - can also be impressive political resources. (Doris Kearns Goodwin, Team of Rivals, 2005)

Most people in leadership positions develop an eye for the talent they are seeking. Members of the team need to share the same values but should have different perspectives and abilities that complement each other, people who work well together, respect one another, and believe in the worth of what they are doing. Good leaders are not threatened by colleagues of superior talent and they understand that another's achievement reflects well on them.

Not everyone in an organization behaves or aligns perfectly, yet many are quite valuable for what they do. Thus, sometimes there is a tension between tolerating some misbehaviors of certain people and benefiting from their contributions. Eugene Stead, an influential academic physician and chair of the Department of Medicine at Duke University from 1947 to 1967, described this dilemma for 
leaders in this pithy remark: "A faculty person has to be worth the trouble he causes." You can substitute "employee," "team member," and other descriptors for "faculty person."

\section{Ability to Know Yourself}

O wad some Power the giftie gie us

To see oursels as ithers see us! (Robert Burns, 1759-1796, To a Louse)

Robert Burns wrote To A Louse after he sat behind a beautiful woman in church one Sunday and observed a louse crawling up her hair onto her bonnet. This stimulated a train of speculation about the impudence of the critter strutting on such a lovely lady and, if some power would give us the gift to see ourselves as others see us, perhaps it would free us from many foolish blunders and make us less pretentious in the way we appear and act.

If you are in the business of leading others, it is helpful to know something about yourself - what motivates you, how you think, why you behave in certain ways. Also, part of knowing yourself is having some understanding of how others regard you. You can learn about this by paying attention to what others say to you and about you and how they react to you, although what they say and do often is conveyed in a sort of code that more or less conforms to social rules and requires interpretation. We all vary in our ability to pick up on the cues that others send and decipher this code. I believe that effective leaders are able to understand how they come across to others and make modifications to correct ineffective behavior and strengthen what is effective. But, should we see ourselves exactly as others see us? We should be thankful that most of us have protective defenses that allow us to get through the day without feeling completely foolish.

\section{Conditions and Contexts of Leadership}

\section{On Reorganization}

We trained hard, but it seemed that every time we were beginning to form into teams, we would be reorganized. I was to learn later in life that we tend to meet any new situation by reorganization, and a wonderful method it can be for creating the illusion of progress while producing confusion, inefficiency, and demoralization. (Petronius, Roman writer, satirist, ca., 27-66) 
No comment required.

\section{Chance and Environmental Circumstances}

Chance plays a role in opportunities for leadership and in the expression of leadership. When, where, and other circumstances of our birth and life, whom we meet, local and world events, and many other factors combine to support or discourage leadership. One lesson for leaders here is to appreciate that many people have the potential for leadership, but may not have it realized because of circumstances. Good leaders look for opportunities to alter circumstances to promote leadership in others.

Following are excerpts from Thomas Gray's Elegy Written in a Country Churchyard (1751), written as he was musing on the people buried there and still living in the adjacent town, that illustrate the effects of chance and circumstances.

Perhaps in this neglected spot is laid

Some heart once pregnant with celestial fire;

Hands, that the rod of empire might have sway'd,

Or waked to ecstasy the living lyre:

Full many a gem of purest ray serene The dark unfathom'd caves of ocean bear: Full many a flower is born to blush unseen, And waste its sweetness on the desert air.

Some village-Hampden, that with dauntless breast

The little tyrant of his fields withstood, Some mute inglorious Milton here may rest, Some Cromwell, guiltless of his country's blood.

\section{Interrelatedness and Interdependence}

We are a strand in the web of life. Whatever we do to the web, we do to ourselves. (Chief Seattle, 1786-1866)

One of the joys of leadership is being in a position that allows one to see how ideas and people relate to each other and to make connections for the improvement of individuals and the organization. I have observed that very little occurs in isolation without consequences elsewhere. For years I have been influenced by the broad application of John Donne's Meditation on a Tolling Bell (1624), the familiar: 
"No man is an Island, intire of itselfe; every man is a peece of the Continent, a part of the maine; if Clod bee washed away by the Sea, Europe is the lesse, as well as if a Promontorie were, as well as if a Mannor of thy friends or of thine owne were; any mans death diminishes me, because I am involved in Mankinde; And therefore never send to know for whom the bell tolls; It tolls for thee."

Donne describes a general truth. In an effort to make his observation relevant to my environment, I changed the particulars thus.

"No person is an Island, intire of itselfe; every person is a peece of this University, a part of the maine purpose; if a \$50 M Clod of

Research Funding bee washed away, our University is the lesse, as well as if thy College were, as well as if a Mannor of thy department colleagues or of thine owne were; any person's misfortune diminishes me, because I am involved in this University; And therefore never send to know for what the bill tells; It may take a toll on thee." (with apologizes to Mr. Donne)

Clearly, removing "university" and substituting "society," “corporation," "department," "church," "family," or any organization creates a nearly universal metaphor.

I can think of no organization, large or small, complex or simple, that does not have both internal and external interdependencies. One of the responsibilities of leadership is to remind and demonstrate that the interdependence is real and necessary.

\section{Leadership to Run the World}

... the world will not be run by those who possess mere information alone... The world henceforth will be run by synthesizers, people able to put together the right information at the right time, think critically about it, and make important choices wisely. (Edward O. Wilson in Consilience: The Unity of Knowledge, 1999)

What kind of leaders does the world need? "Leadership is an essentially moral act," said A. Bartlett Giamatti, former president of Yale University, who later became Commissioner of Baseball. But our experience tells us that there is a large 
disconnection between the notion that leadership is a moral act and the behavior of some leaders in government, business, academia, religion, and elsewhere. That the world needs thoughtful, ethical leadership in all domains I simply accept. Res ispa loquitur.

I believe that the world needs leaders who, to use a common phrase, have a moral compass. But I believe also that we need leaders who can think big - and can think small - simultaneously. Leaders who think and act strategically and tactically at the same time. Leaders who are capable of understanding broad ideas and understanding their application. We need leaders who are broadly educated, who understand history and the social sciences, who appreciate the value of poetry, literature, music, philosophy, mathematics, biology, genetics, physics, engineering, and nanotechnology. We need leaders who understand why all of these disciplines are related, because everything is related. These are leaders who can recruit from a broad knowledge and experience and "put together the right information at the right time, think critically about it, and make important choices wisely."

\section{Final Comment}

These examples are not intended to be authoritative but rather illustrative and an encouragement to others to use their own examples of literature in the teaching of leadership. I am aware, with unambiguous certainty, that each reader could construct a similar exposition, using entirely different examples, and it would be just as instructive, perhaps more so. 


\section{References}

Aisner, J. (2008). HBS course uses literature to teach moral leadership. Harvard Business School release. (http://www.hbs.edu/news/releases/moral.html)

Albert J.A., \& Vadla, K. (2009). Authentic leadership development in the classroom: A narrative approach. Journal of Leadership Education 8(1), 72-92.

Doo, M. Y. (2005). Exploring leadership teaching methods. Academic Exchange Quarterly.

Eastwood, G. L. (1998). Leadership amid change: The challenge to academic health centers. In Mission Management. A New Synthesis. Washington, DC: Association of Academic Health Centers, pp 67-84.

Pillai, R., \& Stites-Doe, S. (2003). Teaching Leadership: Innovative Approaches for the $21^{\text {st }}$ Century. Greenwich, CT: Information Age Publishing, Inc.

Sample, S. B. (2002). The Contrarian's Guide to Leadership. San Francisco, CA: Jossey-Bass.

Shaw, K. A. (2005). The Intentional Leader. Syracuse, NY: Syracuse University Press.

Shaw, M. E. (2006). Business schools teach leadership through fiction. The Virginian-Pilot, Norfolk, VA. May 7, 2006.

(http://www.redorbit.com/news/education/494737/business_schools_teach leadership_through_fiction/index.html) 